\title{
Effect of a BlpC-Based Quorum-Sensing Induction Peptide on Bacteriocin Production in Streptococcus thermophilus
}

\author{
George A. Somkuti ${ }^{1} \&$ J. A. Renye Jr. ${ }^{1}$ \\ ${ }^{1}$ Eastern Regional Research Center, United States Department of Agriculture, Wyndmoor, PA 19038, USA \\ Correspondence: George A. Somkuti, United States Department of Agriculture, Wyndmoor, PA 19038, USA. \\ Tel: 1-215-233-6474. E-mail: george.somkuti@ars.usda.gov
}

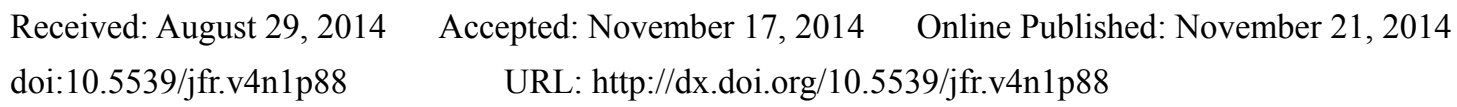

Mention of trade names or commercial products in this publication is solely for the purpose of providing specific information and does not imply recommendation of endorsement by the U.S. Department of Agriculture. USDA is an equal opportunity provider and employer.

\begin{abstract}
Bacteriocin synthesis in some Streptococcus thermophilus strains is under the control of a complex blp locus but bacteriocin is produced only when a quorum-sensing regulatory mechanism is activated by the protein product of the $b l p C$ component. To demonstrate the regulatory effect of BlpC in S. thermophilus ST110 (NRRL-B59671), which naturally produces bacteriocin, the effect of the 30mer quorum-sensing induction peptide (QSIP) embedded in $\mathrm{BlpC}$ was tested in a knockout mutant in which the $b \operatorname{lp} C$ gene was eliminated and was devoid of antimicrobial activity. Between concentrations of 30 and $250 \mathrm{ng} / \mathrm{ml}$, the addition of synthetic QSIP to cultures at several points of the growth curve resulted in the accumulation of up to 3,200 units $/ \mathrm{ml}$ of bacteriocin after $8 \mathrm{~h}$ of growth at $37^{\circ} \mathrm{C}$. Addition of QSIP to the culture in late $\log$ phase $\left(\mathrm{OD}_{660} \geq 1.0\right)$ when the medium $\mathrm{pH}$ is already 4.8 or lower, failed to trigger bacteriocin production. We used synthetic QSIP to survey its impact on 35 strains of $S$. thermophilus that do not display bacteriocin activity by agar diffusion assays. The addition of QSIP (250 $\mathrm{ng} / \mathrm{ml}$ ) to $S$. thermophilus cultures in the early or mid-log phase induced bacteriocin production in two strains that could be re-classified as bacteriocin producers. The results demonstrated the involvement of a quorum-sensing regulatory mechanism in bacteriocin synthesis in S. thermophilus ST110 and also demonstrated the utility of the 30 mer QSIP in discovering bacteriocins with potentially novel antimicrobial spectra by enhancing bacteriocin production in other strains of $S$. thermophilus that ordinarily display a bacteriocin-negative phenotype.
\end{abstract}

Keywords: bacteriocins, Streptococcus thermophilus, blpC gene, quorum-sensing peptide

Abbreviations: QSIP-quorum sensing induction peptide; LAB-lactic acid bacteria; TFA-trifluoroacetic acid; HPLC-high-performance liquid chromatography; PCR-polymerase chain reaction

\section{Introduction}

Streptococcus thermophilus belongs to a group of food grade lactic acid bacteria (LAB) that are essential starter cultures in the production of yogurt and cheeses. Several strains of $S$. thermophilus have been shown to naturally produce bacteriocins that are small, ribosomally produced peptides with narrow and/or broad spectrum antimicrobial activity (Villani et al., 1995; Ward \& Somkuti, 1995; Marciset et al., 1997; Aktypis et al., 1998; Ivanova et al., 1998; Mathot et al., 2003; Gilbreth \& Somkuti, 2005; Fontaine \& Hols, 2008). Genome sequencing of Streptococcus thermophilus strains LMD-9, CNRZ1066 and LMG18311 revealed a cluster of genes encoding potential bacteriocin-like peptides (blp) based on genetic similarities to the class II bacteriocin locus described for $S$. pneumoniae (deSaizieu et al., 2000). Genes encoding potential bacteriocins were identified based on the presence of peptides containing a double glycine leader sequence: including BlpD, U, E, and F in LMD-9; BlpU and $\mathrm{K}$ in LMG18311; and BlpK in CNRZ1066; however under standard culturing conditions all three strains failed to produce active bacteriocins (Hols et al., 2005). In addition, in all three strains the blp locus was also shown to contain genes encoding for a three-component quorum sensing (QS) system, with $b l p H$ and $b l p R$ encoding a putative histidine kinase and response regulator respectively, and $b l p C$ encoding the precursor 
of the quorum sensing induction peptide (QSIP) (Hols et al., 2005). Overexpression of BlpC in S. thermophilus LMD-9 resulted in the identification of a 30-mer secreted peptide $(3403.7 \mathrm{Da})$ representing the mature pheromone, that plays a key role in the display of bacteriocin activity (Fontaine et al., 2007). Production of an active bacteriocin could also be induced in strain LMD-9 when the 30-mer peptide was added to early log phase cultures. However, overexpression of BlpC or extracellular addition of the synthetic peptide had no effect on bacteriocin production in S. thermophilus strains CNRZ1066 and LMG18311 due to mutations in blpB which encodes BlpB, an accessory transport protein required for secretion of the QSIP and bacteriocin peptides (Fontaine et al., 2007). Further analysis of the blp locus in strain LMD-9 showed that expression of BlpD alone was sufficient to inhibit the growth of most target bacteria, but the overall broad spectrum of activity may require expression of multiple peptides (BlpD, U, E, F) and the presence of a thiol-disulfide oxidase encoded by blpG (Fontaine \& Hols, 2008). In addition, immunity to the bacteriocin was dependent on the products of orf 1 and $\operatorname{orf} 2$, located immediately downstream of $b l p D$; and $\operatorname{orf} 7$, located immediately downstream of $b l p E$ (Fontaine \& Hols, 2008).

Although we previously reported the apparently constitutive production of bacteriocins in two $S$. thermophilus strains (Ward \& Somkuti, 1995; Gilbreth \& Somkuti, 2005), information was still needed on the role of various components of the $b l p$ cluster of genes in bacteriocin synthesis. The purpose of this study was to test the involvement of the blpC subunit in bacteriocin production by a mutant culture $(b l p C)$ of $S$. thermophilus strain ST110 and to evaluate the response of other, apparently non-bacteriocin producing strains to the addition of synthetic 30-mer QSIP that was identical to the active peptide present in BlpC of strain LMD-9.

\section{Methods}

\subsection{Synthesis of Quorum-Sensing Induction Peptide (QSIP)}

The 30-mer QSIP (N'-SGWMDYINGFLKGFGGQRTLPTKDYNIPQA-C') present within the gene product of blpC in S. thermophilus LMD-9 (Fontaine et al., 2007) was prepared by microwave-assisted solid phase peptide synthesis with Fmoc (N-(9-fluorenyl) methoxycarbonyl)-protected amino acids, using a CEM Liberty synthesizer, according to the manufacturer's recommended protocol (CEM Corp., Matthews, NC). The peptide was cleaved in the CEM microwave chamber using a 95:2.5:2.5 mix of TFA:triisopropyl-silane: $\mathrm{H}_{2} \mathrm{O}$ for 30 min at $35{ }^{\circ} \mathrm{C}$ and $10 \mathrm{~W}$ power setting. After repeated precipitations in ice cold ether, the peptide was dissolved in $\mathrm{H}_{2} \mathrm{O}$ and analyzed by HPLC (C18 peptide column). The molecular mass of the peptide product (3,403.7 Da) was confirmed by matrix-assisted laser desorption ionization-time of flight mass spectrometry (MALDI-TOF/TOF MS).

\subsection{Bacterial Strains}

S. thermophilus strains were maintained in tryptone-yeast extract-lactose (TYL) medium at $37{ }^{\circ} \mathrm{C}$ (Somkuti \& Steinberg, 1986). Escherichia coli DH5a, used as interim host for subcloning plasmid constructs, was grown in BHI medium. When needed, media was supplemented with erythromycin (Em) at $150 \mu \mathrm{g} / \mathrm{ml}$ (E. coli) or 15 $\mu \mathrm{g} / \mathrm{ml}$ (S. thermophilus) or kanamycin $(\mathrm{Km})$ at $150 \mu \mathrm{g} / \mathrm{ml}$. Pediococcus acidilactici F (gift from B. Ray, University of Wyoming) was maintained in deMan, Rogosa and Sharpe (MRS) broth and inoculated into MRS agar when used as the target organism.

\subsection{Antimicrobial Assays}

Bacteriocin activity of cell-free culture fluids of S. thermophilus ST110 (NRRL- B59671, Agricultural Research Service Culture Collection, NCAUR-USDA, Peoria, IL, http://nrrl.ncaur.usda.gov), and its blpC knockout mutant were tested by an agar diffusion method with Pediococcus acidilactici $\mathrm{F}$ as the target organism in MRS agar, in which each well was filled with $50 \mu$ of sample (Gilbreth \& Somkuti, 2005). The amount of bacteriocin produced was estimated by the spot-on-the-lawn method (Henderson et al., 1996), after a twofold dilution of each sample with sterile distilled $\mathrm{H}_{2} \mathrm{O}$ and depositing $5 \mu \mathrm{l}$ on the surface of 2-mm deep MRS agar plates inoculated with $P$. acidilactici $\mathrm{F}$. The highest dilution showing an inhibition zone was designated as 1 bacteriocin activity unit (AU). Total bacteriocin activity was calculated as the reciprocal of the highest dilution multiplied by a factor of 200 and expressed as AU/ml. In evaluating the effect of QSIP on S. thermophilus strains with $b l p$ phenotype, filtrates of cultures grown for $16 \mathrm{~h}$ without or with added QSIP were tested for bacteriocin activity against $S$. thermophilus ST113 (NRRL-B59386) which was previously noted for high sensitivity to bacteriocins produced by other $S$. thermophilus strains (Ward \& Somkuti, 1995).

\subsection{Conditions for Evaluating Synthetic QSIP}

The presence of the various components of the blp gene cluster in S. thermophilus ST110 with possible role in bacteriocin production was checked by PCR (Perkin-Elmer Thermal Cycler, Model 9700), cycling conditions: 95 
${ }^{\circ} \mathrm{C}$ for $5 \mathrm{~min}$, followed by 30 cycles of $\left(95{ }^{\circ} \mathrm{C}\right.$ for $1 \mathrm{~min}, 50{ }^{\circ} \mathrm{C}, 55^{\circ} \mathrm{C}$ or $60{ }^{\circ} \mathrm{C}$ for $1 \mathrm{~min}, 74{ }^{\circ} \mathrm{C}$ for $1 \mathrm{~min}$, followed by 1 cycle of $74{ }^{\circ} \mathrm{C}$ for $7 \mathrm{~min}$ and a $4{ }^{\circ} \mathrm{C}$ soak. Forward and reverse primers for each blp component tested (Table 1) were designed using the blp locus in S. thermophilus LMD-9 (ATCC BAA-491, American Type Culture Collection, Rockville, MD) as the model (Hols et al., 2005).

Table 1. Primers used to detect components of the blp locus in S. thermophilus

\begin{tabular}{lll}
\hline Target gene & Forward primer, 5' $^{\prime}{ }^{\prime}$ & Reverse primer, 5' $^{\prime}{ }^{\prime}$ \\
\hline$b l p A / b l p B^{a}$ & ACGCTATTGAAGGTGCCATT & \\
$b l p C$ & TTTGTTGGAAGCGTTCTTTG & CACTTGATAACCACGCTCTTGA \\
$b l p D$ & CTACTAACACCCCACCGACAG & TGGCAACTCAAACAATTGAAA \\
$b l p U$ & TCACCACCAGCATGTTGCTC & AAGGTGGTGGATGTAGCTGGG \\
$b l p K$ & CATTACCTCCAAACGCTCCT & TGGCAACTCAAACAATTGAAA \\
$b l p E$ & TGCACCTACTGCACCAGTTC & ACACCCTCGACCTTGAAACA \\
$b l p F$ & ACCATGGGATAGGCTTCACC & TCAAGGTGGTGCTGTTTGTC \\
$b l p H$ & TTGGGATGGAGACTCTGGAC & TCCCTTGTTGGAGACACCTC \\
\hline
\end{tabular}

${ }^{\mathrm{a}}$ sequences determined by primer walking.

PCR products were cleaned up for sequencing using Ampure reagent (Agencourt, www.agencourt.com). Sequencing was performed in an ABI 3730 DNA Analyzer (Applied Biosystems), and sequences were trimmed and aligned using Sequencher software (Genecodes Corp., Ann Arbor, MI). Nucleotide sequences were compared to sequences in the NCBI database using BLASTn at http://www.ncbi.nlm.nih.gov/.

A control strain of S. thermophilus ST110 lacking $b l p C$ (knockout mutant) was developed by a gene inactivation technique using the integrative vector $\mathrm{pKS} 1$, which contains a temperature-sensitive origin of replication and genes encoding for erythromycin and kanamycin resistance (Shatalin \& Neyfakh, 2005). DNA fragments corresponding to the 3' ends of blpB (708 bp) and blpH (701 bp) were amplified by PCR followed by the purification of fragments using the QIAquick PCR purification kit (Qiagen Inc, Valencia, CA) and cloned into pKS1 at the corresponding restriction endonuclease recognition sites. The resulting vector pSTKOC was transformed into freshly prepared E. coli competent cells by a standard heat-shock method (Sambrook et al., 1989) and propagated at $37^{\circ} \mathrm{C}$. Plasmid was recovered from E. coli by alkaline lysis followed by CsCl/ethidium bromide ultracentrifugation (Stougaard \& Molin, 1981) and introduced by electrotransformation into $S$. thermophilus ST110 according to a previously described protocol (Somkuti \& Steinberg, 1988). Chromosomal integration of the vector was accomplished by a two-step homologous-recombination protocol (Renye \& Somkuti, 2012).

The effect of QSIP on bacteriocin production was tested by adding QSIP $(250 \mathrm{ng} / \mathrm{ml})$ at different time intervals to cultures of $S$. thermophilus ST110 and its knockout mutant growing in TYL. QSIP was also added to a growing culture of the knockout mutant to evaluate the effect of QSIP concentration $(30-250 \mathrm{ng} / \mathrm{ml})$ on bacteriocin production with Pediococcus acidilactici $\mathrm{F}$ as the test organism.

The effect of QSIP was also tested in a group of 35 laboratory strains of $S$. thermophilus with blp phenotype with no antimicrobial activity against $S$. thermophilus ST113. QSIP was added at $250 \mathrm{ng} / \mathrm{ml}$ final concentration at different times during growth and after $16 \mathrm{~h}$ at $37^{\circ} \mathrm{C}$, culture filtrates were tested by the agar diffusion assay for activity against $S$. thermophilus ST113.

\subsection{Real-time PCR Analysis}

S. thermophilus strains were grown in TYL medium until the culture reached an $\mathrm{OD}_{660}$ between 0.8 and 1.0 . RNA was extracted using the RiboPure ${ }^{\mathrm{TM}}$-Bacteria kit (Ambion-Life Technologies, Grand Island, NY). Residual DNA was removed with DNase I treatment (Ambion) for 30 minutes at $37^{\circ} \mathrm{C}$. RT-PCR was performed using an Applied Biosystems 7500 Fast RT-PCR system (Life Technologies). Cycling conditions were: 40 cycles of 95 ${ }^{\circ} \mathrm{C}$ for $30 \mathrm{~s}, 45^{\circ} \mathrm{C}$ for $30 \mathrm{~s}$ and $60{ }^{\circ} \mathrm{C}$ for $30 \mathrm{sec}$., and a melt curve analysis was performed from $60-95^{\circ} \mathrm{C}$ with fluorescence readings taken continuously after a $1 \%$ increase in temperature. cDNA synthesis and RT-PCR were carried out in a single step using the SuperScript III Platinum SYBR Green One-Step qRT-PCR kit (Life Technologies) with a total RNA concentration of $1 \mu \mathrm{g}$ for amplification of blp components, and $10 \mathrm{ng}$ for $16 \mathrm{~S}$ 
rRNA as the reference. The ABI 7500 Fast software was used to determined $\mathrm{C}_{\mathrm{T}}$ values, and the relative quantification of gene expression was determined using the $2^{-\Delta \Delta C T}$ method (Livak \& Schmittgen, 2001), where $\Delta \mathrm{C}_{\mathrm{T}}=\mathrm{C}_{\mathrm{T}}$ (target) $-\mathrm{C}_{\mathrm{T}}$ (reference), and $\Delta \Delta \mathrm{C}_{\mathrm{T}}=\mathrm{C}_{\mathrm{T}}(+\mathrm{QSIP})-\mathrm{C}_{\mathrm{T}}(-\mathrm{QSIP})$. Results are reported from a minimum of three independent RT-PCR reactions ( \pm standard deviation).

\section{Results and discussion}

\subsection{Detection of Blp Components in S. thermophilus ST110}

Bacteriocin production in $S$. thermophilus is dependent on the presence of the blp gene cluster that was previously described in several strains, including LMD-9, LMG18311 and CNRZ1066 (Hols et al., 2005) and the functionality of its various components was studied in several strains (Fontaine et al., 2007). Based on PCR analysis and nucleotide sequence data, gene products containing a double glycine leader sequence and qualifying as potential bacteriocins include BlpD, U, E and F in strain LMD-9 (ATCC, BAA-491), BlpU and K in strains LMG18311 (ATCC, BAA-250) and S. thermophilus ST110 (NRRL-B59671), and BlpK in strain CNRZ1066 (Hols et al., 2005)(Table 2).

Table 2. Blp components with gly-gly leader peptides in S. thermophilus strains

\begin{tabular}{ccccc}
\hline Peptide & ST110 & LMD-9 & LMG18311 & LMD-9 \\
\hline BlpD & & + & & \\
BlpU & + & + & + & + \\
BlpK & & & + & \\
BlpE & & + & & \\
BlpE & & + & & \\
\hline
\end{tabular}

Based on research on the functionality of various blp components in knockout mutants of $S$. thermophilus LMD-9, it was previously concluded that the $b l p D$ component alone may be responsible for bacteriocin activity (Fontaine \& Hols, 2008). However, the absence of blpD in S. thermophilus ST110 as shown by PCR analysis indicated that bacteriocin synthesis in this strain is controlled by other components of the blp locus.

According to the LMD-9 model (Fontaine et al., 2007), the product of blpC, a 53-mer protein (BlpC) includes the 30-mer QSIP peptide N'-SGWMDYINGFLKGFGGQRTLP-TKDYNIPQA-C' that plays a key role in activating the cascade of events leading to bacteriocin synthesis. It was also found that although some $S$. thermophilus strains (e.g. LMD-9) have a functional blpC component, the amount of BlpC gene product is not adequate to activate bacteriocin synthesis (Fontaine \& Hols, 2008) but externally supplied QSIP induced bacteriocin production.

\subsection{Restoration of Bacteriocin Production in S. thermophilus ST110 blpC knockout mutant}

Following electrotransformation with the pSTKOC integrative vector, S. thermophilus ST110 transformants were resistant to both erythromycin and kanamycin when grown at $32{ }^{\circ} \mathrm{C}$ (permissible temperature for plasmid replication). Subsequent transfers at $42{ }^{\circ} \mathrm{C}$ resulted in a single homologous recombination event with the entire plasmid inserted into the $b l p$ gene cluster. Clones confirmed by PCR to have the single crossover within the $b l p$ gene cluster were further transferred at $30^{\circ} \mathrm{C}$ which allowed for the second recombination event to occur, replacing $b l p C$ with the kanamycin marker gene. Removal of $b l p C$ from the blp gene cluster resulted in the loss of bacteriocin activity as indicated by the absence of an inhibition zone in agar diffusion assays. However, when the mutant culture lacking $b l p C$ was supplemented at various time intervals with QSIP at $250 \mathrm{ng} / \mathrm{ml}$, bacteriocin production was restored (Figure 1 and Figure 2). The optimum time of QSIP addition to induce bacteriocin production was between 0 and $4 \mathrm{~h}$ after the start of incubation and the amount of bacteriocin produced after $8 \mathrm{~h}$ of incubation was estimated at 3,200 AU/ml (Figure 1). 


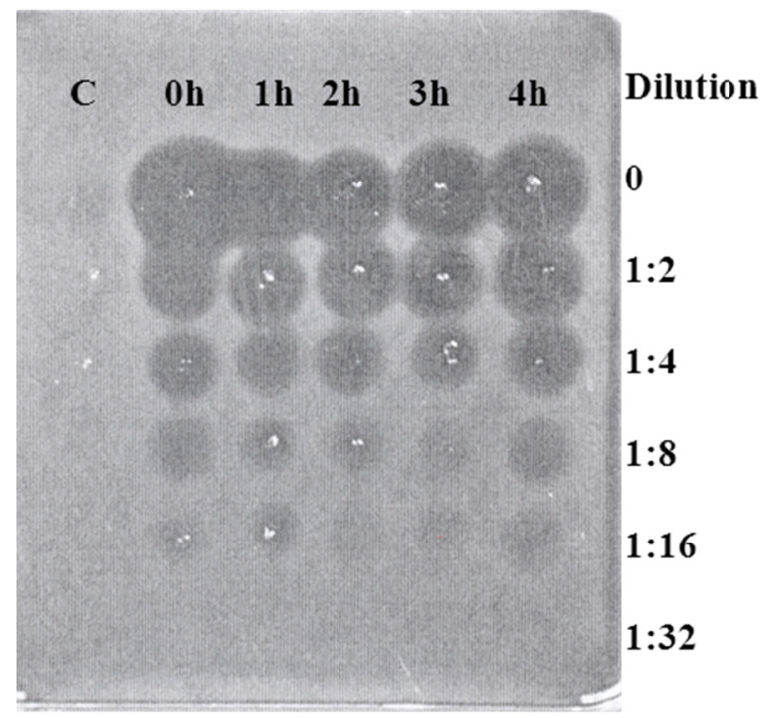

Figure 1. Effect of the 30mer QSIP on bacteriocin synthesis in S. thermophilus ST110 (NRRL-B59671) knockout mutant ( $b l p C^{-}$) Top (left to right): C, control (no added QSIP); time of addition of adding QSIP at 250 $\mathrm{ng} / \mathrm{ml}$ to a culture grown at $37^{\circ} \mathrm{C}$. Right: degree of dilution of cell-free culture fluids. Target lawn: Pediococcus acidilactici $\mathrm{F}$.

When QSIP was added after $6 \mathrm{~h}$ of growth, it failed to restore bacteriocin production by the knockout mutant. The amount of QSIP also influenced bacteriocin production similar to that reported for S. thermophilus LMD-9 (Fontaine et al., 2007). In the case of the $S$. thermophilus ST110 blpC- knockout mutant, the estimated amount of bacteriocin produced did not appear to change at $60 \mathrm{ng} / \mathrm{ml}$ or higher QSIP concentration (Figure 2).

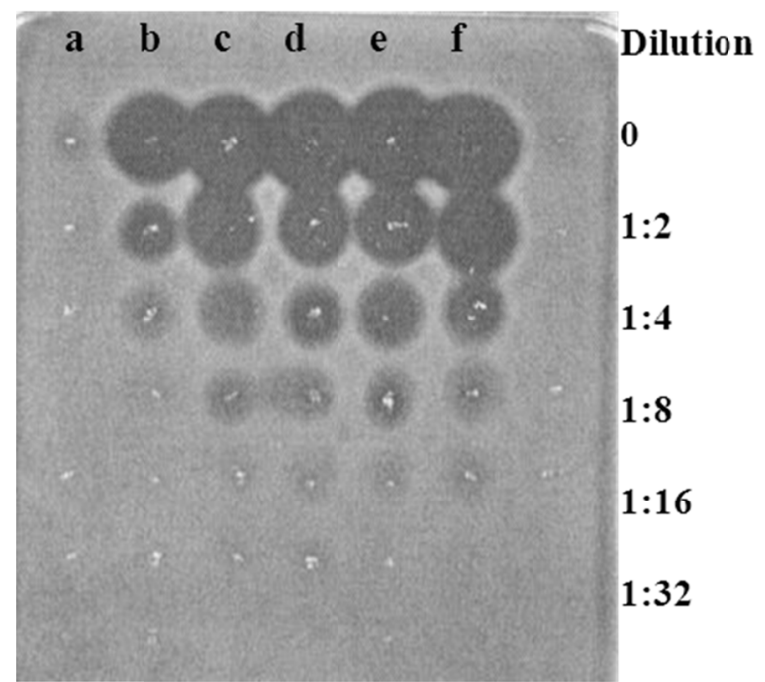

Figure 2. Effect of QSIP concentration on bacteriocin synthesis in S. thermophilus ST110 (NRRL-B59671) knockout mutant $\left(b l p C^{\circ}\right)$. QSIP was added $4 \mathrm{~h}$ following the start of incubation at $37^{\circ} \mathrm{C}$. Top (left to right): QSIP at 0 (a), $31 \mathrm{ng} / \mathrm{ml}$ (b), $62 \mathrm{ng} / \mathrm{ml}$ (c), $125 \mathrm{ng} / \mathrm{ml}$ (d), $187 \mathrm{ng} / \mathrm{ml}$ (e) and $250 \mathrm{ng} / \mathrm{ml}$ (f). Right: degree of dilution of cell-free culture fluids. Target lawn: Pediococcus acidilactici F. 


\subsection{Impact of the blpC Gene Product QSIP on Bacteriocin Production}

We tested the effect of synthetic 30-mer QSIP preparations on bacteriocin synthesis in a group of laboratory strains of $S$. thermophilus that included both $b l p^{+}$and $b l p^{-}$phenotypes. Aqueous stock solutions of lyophilized QSIP were prepared at $100 \mu \mathrm{g} / \mathrm{ml}$ and the peptide was added to each $S$. thermophilus culture after $4 \mathrm{~h}$ of growth at $37^{\circ} \mathrm{C}$, at a final concentration of $250 \mathrm{ng} / \mathrm{ml}$ with incubation continuing for $8 \mathrm{~h}$ at $37^{\circ} \mathrm{C}$. Samples taken from each culture were centrifuged in an Eppendorf microfuge at $10,000 \mathrm{rpm}$ and $4{ }^{\circ} \mathrm{C}$ for $10 \mathrm{~min}$. Cell-free supernatants were tested for bacteriocin activity by the agar diffusion antimicrobial assay using $S$. thermophilus strain ST113 as the target.

The results showed that in the case of the constitutively bacteriocin producers $\left(b l p^{+}\right)$strains ST109 and ST114, additional QSIP was without effect (Figure 3a).

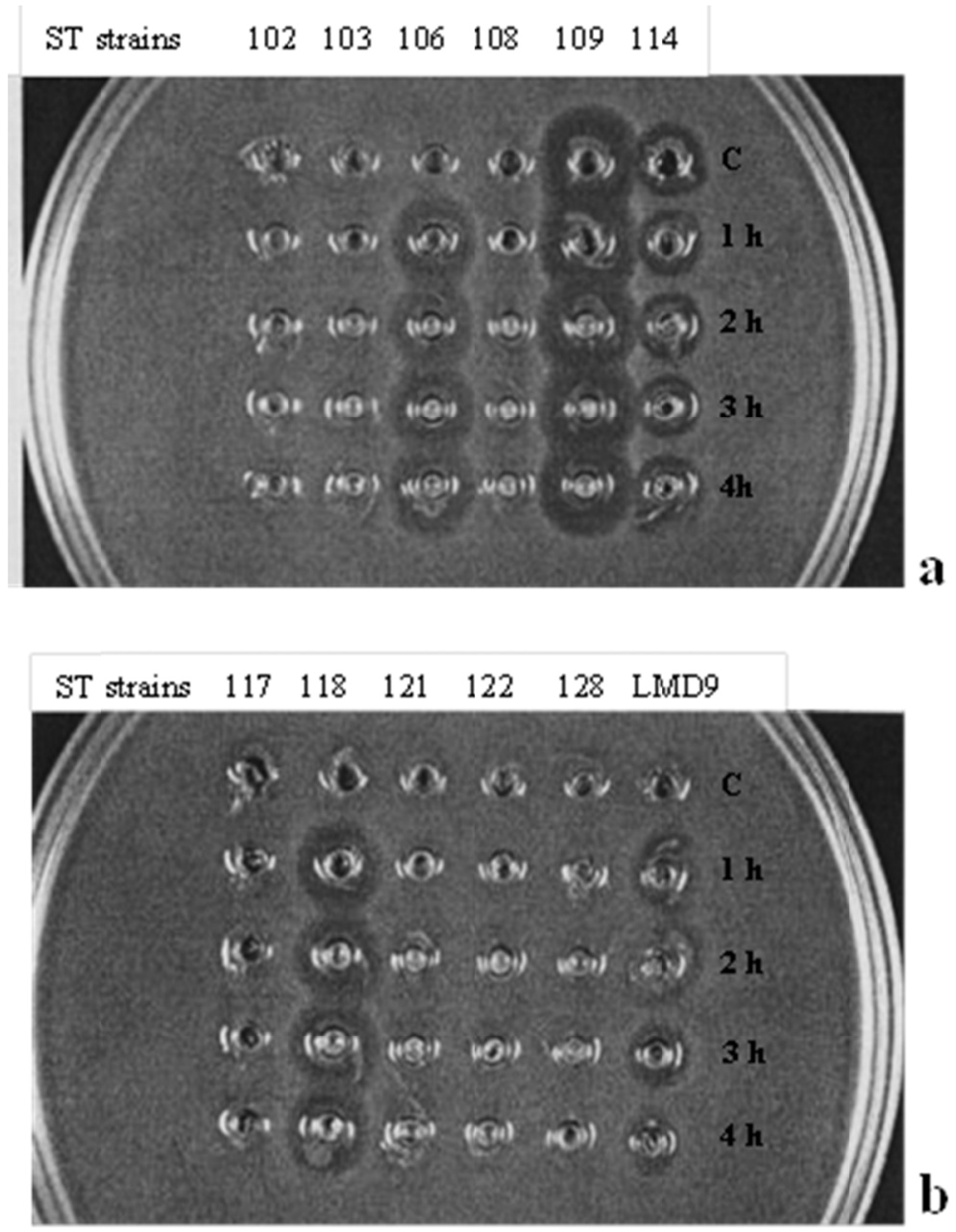

Figure 3 a, b. Response of selected bacteriocin-producing (ST109, ST114) and phenotypically bacteriocin negative strains of S. thermophilus to the addition of QSIP at $250 \mathrm{ng} / \mathrm{ml}$ to growth medium. Right: time of QSIP addition; C: control, without added QSIP. Target lawn: Streptococcus thermophilus ST113

On the other hand, supplementation of the medium (TYL) with QSIP led to the detection of two additional strains (ST106, Figure 3a) and (ST118, Figure 3b) that similar to the control strain LMD-9 (Figure 3b, Hols et al., 2005), responded to exogenous QSIP and displayed a $b l p^{+}$phenotype as evidenced by visible zones of inhibition in the lawn of the test organism. Similar to what was observed with the ST110 blpC knockout mutant, the addition of QSIP at $250 \mathrm{ng} / \mathrm{ml}$ at $1 \mathrm{~h}$ to $4 \mathrm{~h}$ of culture growth and continuing incubation at $37^{\circ} \mathrm{C}$ for an additional $4 \mathrm{~h}$, did not result in a detectable change in bacteriocin production (Figure $3 \mathrm{~b}$ ) as indicated by the appearance of inhibition zones. These results were similsr to data reported for as the model strain LMD-9 that was previously shown to respond to exogenous QSIP (Fontaine et al., 2007). While the addition of QSIP did not appear to have 
a measurable effect on the zones of inhibition displayed by the constitutive bacteriocin-producing strains ST109 and ST114, it is possible that the bacteriocin(s) induced by QSIP in ST106 and ST118 may have novel properties that merit further investigation.

PCR analysis of the blp loci confirmed the presence of $b l p A, b l p B, b l p C, b l p D, b l p E$ and $b l p H$ in ST106 and ST118 as well as LMD-9 (Figure 4). In addition, unlike in LMD-9, blpK was detected in both ST106 and ST118. Sequencing of the blp loci by the chromosomal walking technique revealed differences in the length of each locus that were calculated as 13,365 bp in ST106, 14,991 bp in ST118, in comparison with 12,239 bp in LMD-9 (Makarova et al., 2006).

\section{LMD9}
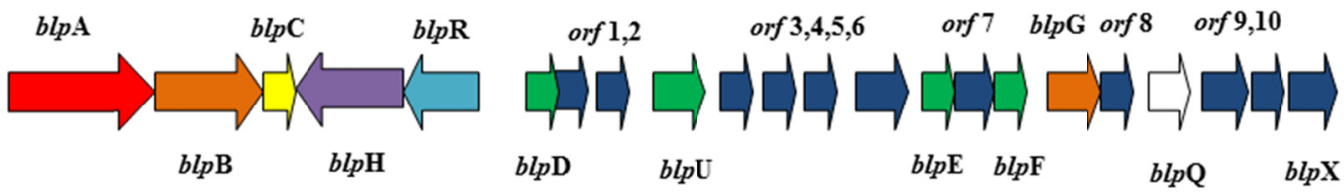

ST106
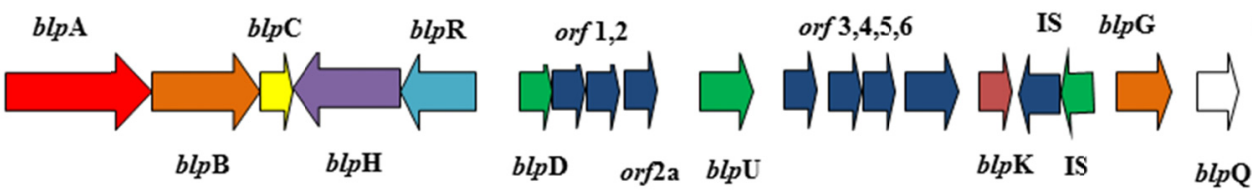

orf 9,10

ST118
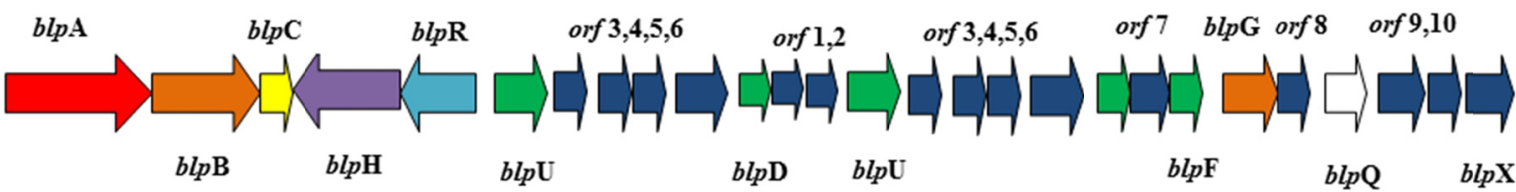

Figure 4. Composition of the blp locus in the Streptococcus thermophilus strains LMD-9, ST106 and ST118

Comparative analysis also showed that each blp locus, if present, shared 95+ per cent homology with the corresponding locus in the other two strains. An interesting feature of the blp locus in ST106 was the presence of two insertion elements (ISa and ISb) that were absent in the blp locus of LMD-9 and shared $100 \%$ homology with each of the corresponding 4 copies of IS elements reported for the genome of LMD-9 (Makarova et al., 2006). In addition, the ST118 blp locus was characterized by a second copy of a sequence involving blpU and orf $3,4,5,6$, that is located between $b l p R$ and $b l p D$ (Figure 4). The effect of these additional features, if any, on the functionality of the blp locus in ST106 and ST118 will require more work.

Real-time PCR analysis was used to measure the expression of specific components within the blp loci. When ST106 and LMD-9 were induced with a synthetic QSIP the expression of $b l p C$ increased by $79( \pm 27)$ and 45 $( \pm 24)$ fold respectively. Since $b l p C$ encodes the endogenous QSIP, it was expected that a higher concentration of $\mathrm{BlpC}$ would result in increased expression other blp components, which was observed as blpD expression in ST106 and LMD-9 increased by $108( \pm 30)$ and $67( \pm 31)$ fold respectively. Since $b l p D$ was previously reported to be essential for bacteriocin activity in LMD-9 (Fontaine \& Hols., 2008), its increased expression in ST106 may explain why it produced larger zones of inhibition when compared to LMD-9 (Figure 3). Following induction with QSIP, the level of $b l p C$ expression in ST118 increased by $138( \pm 46)$ fold but unexpectedly, resulted only in a $15( \pm 8)$ fold increase in $b l p D$ expression. Expression of blpU was tested since it was present in all three strains, and was shown to increase by $6( \pm 4)$ fold in ST118 and 2-fold in ST106 and LMD-9 after induction. The slightly higher expression of $b l p U$ in ST118 may be due to the unique duplication of this gene within its blp locus (Figure 4). 
Induced expression of blpK was also tested since it may encode a unique bacteriocin component in strains ST106 and ST118, and was shown to increase by $198( \pm 15)$ and $24( \pm 3)$ fold, respectively. The high level of expression observed for blpK in ST106 suggests that it may be required for optimal production of the ST106 bacteriocin(s). Expression of the blpRH operon was also tested in all three strains, but as reported previously its expression was not significantly altered $(\leq 2)$ in response to the addition of exogenous QSIP (Fontaine et al., 2007).

\section{Conclusions}

The results confirmed the pivotal role of $b l p C$ in the production of bacteriocins in $S$. thermophilus ST110 (NRRL-B59671). Since $S$. thermophilus is designated as food grade and various strains are used as essential biocatalysts in the industrial production of fermented dairy foods, the capacity to produce antimicrobial peptide(s) imparts them added value and may improve the level of protection against bacterial contamination. The results also demonstrated that QSIP is a valuable screening tool in identifying $S$. thermophilus strains that may produce potentially novel bacteriocins by restoring or improving the functionality of a compromised $b l p C$ component of the $b l p$ cluster of genes.

\section{Acknowledgments}

The authors thank D. Steinberg and M. Toht for technical assistance, D Needleman for assistance with nucleic acid sequencing and A. Nunez for MALDI-TOF/TOF-MS support.

\section{References}

Aktypis, A., Kalantzopoulos, G., Huis in’t Veld, J. H. J., \& ten Brink, B. (1998). Purification and characterization of thermophilin T, a novel bacteriocin produced by Streptococcus thermophilus ACA-DC 0040. Journal of Applied Microbiology, 84, 568-576. http://dx.doi.org/10.1046/j.1365-2672.1998.00383.x

de Saizieu, A., Gardes, C., Flint, N., Wagner, C., Kamber, M., Mitchell, T. J., ... Lange, R. (2000). Microarray-based identification of a novel Streptococcus pneumoniae regulon controlled by an autoinduced peptide. Journal of Bacteriology, 182, 4696-4703. http://dx.doi.org/10.1128/JB.182.17.4696-4703.2000

Fontaine, L., Boutry, C., Guedon, E., Guillot, A., Ibrahim, M., Grossiord, B., \& Hols, P. (2007). Quorum-sensing regulation of the production of Blp bacteriocins in Streptococcus thermophilus. Journal of Bacteriology, 189, 7195-7205. http://dx.doi.org/10.1128/JB.00966-07

Fontaine, L., \& Hols, P. (2008). The inhibitory spectrum of thermophilin 9 from Streptococcus thermophilus LMD-9 depends on the production of multiple peptides and the activity of BlpGST a thiol-disulfide oxidase. Appled and Environmental Microbiology, 74, 1102-1110. http://dx.doi.org/10.1128/AEM.02030-07

Gilbreth, S. E., \& Somkuti, G. A. (2005). Thermophilin 110: a bacteriocin of Streptococcus thermophilus ST110. Current Microbiology, 51, 175-182. http://dx.doi.org/10.1007/s00284-005-4540-7

Henderson, J. T., Chopko, A. L., \& van Wassenaar, P. D. (1996). Purification and primary structure of pediocin PA-1 produced by Pediococcus acidilactici PAC-1.0. Archives of Biochemistry and Biophysics, 295, 5-12. http://dx.doi.org/10.1016/0003-9861(92)90480-K

Hols, P., Hancy, F., Fontaine, L., Grossiord, B., Prozzi, D., Leblond-Bourget, N., ... Kleerebezem, M. (2005). New insights in the molecular biology and physiology of Streptococcus thermophilus revealed by comparative genomics. FEMS Microbiology Reviews, 29, 435-463. http://dx.doi.org/10.1016/j.femsre.2005.04.008

Ivanova, I., Miteva, V., Stfanova, T. S., Pantev, A., Budakov, I., Danova, S., ... Boyaval, P. (1998). Characterization of a bacteriocin produced by Streptococcus thermophilus 81. International Journal of Food Microbiology, 442, 147-158. http://dx.doi.org/10.1016/S0168-1605(98)00067-1

Livak, K. J., \& Schmittgen, T. D. (2001). Analysis of relative gene expression data using real-time quantitative PCR and 2(-Delta Delta C(T)) Method. Methods, 25, 402-408. http://dx.doi.org/10.1006/meth.2001.1262

Makarova, K., Slesarev, A., \& Wolf, Y. (2006). Comparative genomics of the lactic acid bacteria. Proceedings of the National Academy of Sciences USA, 103, 15611-15616. http://dx.doi.org/10.1073/pnas.0607117103

Marciset, O., Jeronimus-Stratingh, M. C., Mollet, B., \& Poolman, B. (1997). Thermophilin 13, a nontypical antilisterial poration complex bacteriocin, that functions without a receptor. Journal of Biological Chemistry, 272, 14277-14284. http://dx.doi.org/10.1074/jbc.272.22.14277

Mathot, A. G., Beliard, E., \& Thuault, D. (2003). Streptococcus thermophilus produces a bacteriocin potentially suitable for inhibition of Clostridium tyrobutyricum in hard cheese. Journal of Dairy Science, 86, 3068-3074. http://dx.doi.org/10.3168/jds.S0022-0302(03)73906-X 
Renye, J. A, Jr, \& Somkuti, G. A. (2012). Vector-mediated chromosomal integration of the glutamate decarboxylase gene in Streptococcus thermophilus. Biotechnology Letters, 34, 549-555. http://dx.doi.org/10.1007/s10529-011-0802-6

Sambrook, J., Maniatis, T., \& Fritsch, E. F. (1989). Molecular cloning: a laboratory manual (2nd ed.), New York: Cold Spring Harbor Laboratory Press.

Shatalin, K. Y., \& Neyfakh, A. A. (2005). Efficient gene inactivationin Bacillus anthracis. FEMS Microbiology Letters, 245, 315-319. http://dx.doi.org/10.1016/j.femsle.2005.03.029

Somkuti, G. A., \& Steinberg, D. H. (1986). Distribution and analysis of plasmids in Streptococcus thermophilus. Journal of Industrial Microbiology, 1, 157-163. http://dx.doi.org/10.1007/BF01569267

Somkuti, G. A., \& Steinberg, D. H. (1988). Genetic transformation of Streptococcus thermophilus by electroporation. Biochemie, 70, 579-585. http://dx.doi.org/10.1016/0300-9084(88)90095-8

Stougaard, P., \& Molin, S. (1981). Vertical dye-buoyant density gradients for rapid analysis and preparation of plasmid DNA. Analytical Biochemistry, 118, 191-193. http://dx.doi.org/10.1016/0003-2697(81)90177-9

Villani, F., Pepe, O., Mauriello, G., Salzano, G., Moschetti, G., \& Coppola, S. (1995). Antilisterial activity of thermophilin 347, a bacteriocin produced by Streptococcus thermophilus. International Journal of Food Microbiology, 25, 179-190. http://dx.doi.org/10.1016/0168-1605(94)00153-W

Ward, D. J., \& Somkuti, G. A. (1995). Characterization of a bacteriocin produced by Streptococcus thermophilus ST134. Applied Microbiology and Biotechnology, 43, 330-335. http://dx.doi.org/10.1007/BF00172834

\section{Copyrights}

Copyright for this article is retained by the author(s), with first publication rights granted to the journal.

This is an open-access article distributed under the terms and conditions of the Creative Commons Attribution license (http://creativecommons.org/licenses/by/3.0/). 